\title{
Bothering to Look: Beyond the Maternal to Ethical Responsibility in Madonna
}

Seunghei Clara Hong*

Ŏmma and ̌̆mmŏni, meaning "mom" and "mother," often evoke sentiments of devotion, sacrifice, and strength in Korea. This is such the case that when writing about a possible "cultural icon" for Korea, columnist Kim Seung-kon even suggests the "Korean mother": a "unique and exceptional" "life-saving force" ceaselessly nurturing, embracing, and comforting. ${ }^{1}$ Indeed, as he notes, the mother has "a special place in Korean culture." Through the trials and tribulations of Korea's modernity, women-as-mothers have supported the family (and, by extension, the nation) economically and emotionally, and nowhere is this more clearly manifested than in cultural productions-including film. From sentimental melodramas of the golden age 1960s to mystery-noir thrillers of recent times, mothers have been a staple in Korean cinema. Whether glorified, punished, or redeemed, women have been repeatedly represented as sacrificial and life-saving so as to solidify this idea(l) of motherhood.

Recently, however, audiences - especially the industry's most coveted female audiences in their 20 s and 30 s- have begun to openly express

* Assistant Professor, Underwood International College, Yonsei University, Seoul.

1 Kim Seung-kon, "Korean Mother: A Cultural Icon," The Korea Herald, trans. Yu Kun-ha, September 17, 2013. Kim Seung-kon is professor of English at Seoul National University and was president of the Literature Translation Institute of Korea from 2012 to 2018. 
ennui with such representations of women. Since 2015, the gender discourse has exploded - with the help of online platforms - from the halls of the university to the streets. ${ }^{2}$ When, in the spring of 2016, a mentally disturbed man, who claimed to have been "belittled by women" all his life, randomly stabbed to death a 23 -year-old woman in the bustling Kangnam Station area, young women banded to change the public discourse on gender. ${ }^{3}$ Staging protests, organizing vigils, and rallying solidarity, they enflamed an unprecedented interest in and awareness of gender issues. ${ }^{4}$ These were also tech-savvy women who, through social media, organized viewings, created word-of-mouth, and influenced ticket sales for "women's films," starring strong, subversive women, such as Sin Suwŏn's drama Madonna (2015), Park Chan-wook's lesbian caper Agassi (The Handmaiden, 2016), and Yi Kyŏngmi's revenge thriller Pimirŭn ŏptta (The Truth Beneath, 2016).

Yet these films were not without controversy. Many film audiences, critics, and scholars alike criticized Madonna for its punishing portrayal of working-class women, The Handmaiden for its voyeuristic male gaze, and The Truth Beneath for its "insensitive use of spy-cams," leading film critic Nam Taŭn to proclaim that "women's films" have "not yet arrived" in South Korea. ${ }^{5}$ Noting how women's films can be simultaneously sub-

2 Isabella Steger, "An Epic Battle Between Feminism and Deep-Seated Misogyny is Under Way in South Korea," Quartz, October 24, 2016.

3 Koo Se-woong, "South Korea's Misogyny," The New York Times, June 13, 2016; Yi Tayŏng, "Gangnam Murder Case Triggers Debate on Misogyny and Mental Illness in Korea," The Korea Herald, May 21, 2016.

4 Kim Chihyŏn, "Kangnamyŏk sagŏnihu: 2030, p'eminijŭm yŏlgong" (In the Aftermath of the Kangnam Station Incident: Women in 20s and 30s Studiously Engage in Feminism), Hankook Ilbo, May 18, 2017; Pak Suji, "Yŏng'yŏng p'emiǔi t'ansaeng: kangnamyŏk sippŏn ch'ulgu, wurisalmŭl pakkwŏtta" (The Birth of 'Young-Young Feminism': How Kangnam Station Exit 10 Changed Our Lives), Hankyoreh, May 16, 2017.

5 Nam Taŭn, "Yŏsŏng'yŏng'hwanŭn ajik toch'ak'aji anatta: Agassiwa pimirŭn ŏpttarŭl pogo," (Women's Films Have Not Yet Arrived: Upon Seeing The Handmaiden and The Truth Beneath), Munhak tongne 23, no. 3, September 2016: 1-13; Dju- 
versive and submissive, film scholar Jeanine Basinger calls it a "deceptive" genre, "Everything the woman's film is, it also isn't. Everything it endorses, it undermines. Everything it destroys, it reaffirms." ${ }^{\prime 6}$ In this paper, I examine Madonna, a film that calls attention to two painfully independent women and then seemingly confounds their identities by redeeming them through the trope of life-saving motherhood. It is worth asking, therefore, what a "woman's film" like Madonna can do beyond being "deceptive" or paradoxical. I argue that, in its very contradictions, Madonna not only challenges motherhood as "natural" to women, it also shows how a woman's film can expand the frame of motherhood to open up a more compassionate and ethical exploration of life and what it means to be human.

Director Sin Suwŏn arrived late to the Korean film scene. She was already thirty-three when she quit her job as a middle school teacher, enrolled in Korea National University of Arts, and turned to screenwriting and directing. ${ }^{7}$ While not (yet) a household name, she has garnered critical acclaim from the outset: her first short Sunhwansŏn (Circle Line, 2012) won Best Short Film at the Cannes Film Festival; her sophomore film Myŏng'wangsŏng (Pluto, 2012) won Special Mention at the Berlin Film Festival; Madonna (2015) was invited to screen in the Un Certain Regards at Cannes; and her latest Yurijŏng'wŏn (Glass Garden, 2017) opened the Busan International Film Festival. From unemployed men to

na, “Madonna, yŏng'hwa hanp'yŏnŭrŏ sesang'i pakkwijin ank'ejjiman” (One Movie Cannot Change a World, and Yet...), enterMedia, July 19, 2015.

6 Jeanine Basinger, A Woman's View: How Hollywood Spoke to Women, 1930-1960 (Middletown, CT: Wesleyan University Press, 1993), 7.

7 Pak Chŏngho, "Nŭtkkagi megap'on, segyeesŏ injŏngbadŭn ŏkch'ŏk ajumma" (Late-Blooming Director: A Hard-Scrapping Ajumma Now Recognized by the World)", Joongang Ilbo (Joongang Daily), July 11, 2015. The term ajumma generally refers to middle-aged and/or married woman, but is also used derogatorily to describe aggressive, often crass, and scrappy women. While Pak Chŏngho does not use the term condescendingly, he does insist on questioning Sin Suwŏn's role as a wife and mother, which she quickly dismisses. 
high school outcasts to homeless or disabled women, Sin Suwŏn tends to focus on the lives of society's most marginalized. Although she claims that it is not her intention to advance "social criticism," she adds that she is ineluctably drawn to the so-called "losers of Korean society.",

Madonna tells the story of two such "loserly" women: Haerim, an emaciated and cynical nurse's aide at a VIP Ward, and Mina, a buxom and naïve prostitute who washes up, comatose, at this hospital. ${ }^{9}$ When an old billionaire, barely kept alive with the help of tubes and black-market organs, shows signs of heart failure, his haughty and selfish son contracts Haerim to "harvest" Mina's organs. ${ }^{10}$ As Haerim looks into and, consequently, is drawn into Mina's life, we are made privy to (two) lives marked by abuse and suffering. In her press previews and interviews, Sin Suwŏn stated that the script for Madonna came about when she chanced upon a young homeless woman dozing in a café and was struck by the utter incongruity of an ostensibly "normal-looking" woman, her wretched state, and the affluent neighborhood. ${ }^{11}$ Gripped by the "horror" that any woman, including herself, could fall into such abject precarity, she constructed the characters of Haerim and Mina.

Perhaps reflecting this sense of horror felt by the director, Madonna begins with the trappings of a taut thriller. The plot centers on investigation and the narrative begins the action in the present and moves between

8 Chin Hyŏnch'ŏl, “Chumok'asira Kwŏn Sohyŏn'kwa Sin Suwŏn kamdok'ŭi Madonna" (Take Note of Kwŏn Sohyŏn and Sin Suwŏn of Madonna), Maeil Business News, July 2, 2015.

9 Madonna, director Sin Suwŏn, Little Big Pictures, 2015 (all translations are mine).

10 While reviews and interviews refer to father and son as Ch'ŏlho and Sang'u, they are never called by name in the film. All of the characters call them "hoejang-nim" (Mr. Chairman) and "sajang-nim" (Mr. President) and even the end credits refer to them simply as hoejang (Chairman) and sajang (President). Their gender and lack of names position them as the sordid and ruthless faces of patriarchal neoliberal capitalism.

11 "Un Certain Regard: Interview with Shin Su-won," Festival de Cannes website, 2015. 
past and present. From its opening title sequence, Haerim and Mina are portrayed as abject and monstrous. Amid the noise of barking dogs, the camera slowly tracks the bottom of a bridge and lingers briefly on Mina carelessly splayed atop a rocky levee-face bloodied, eyes closed, stockings torn, and belly protruding upward. The camera then resumes its movement towards the river, and, after the title, shows a fully dressed Haerim wading through a wide expanse of calm water. As she releases her grasp, a suitcase plummets to the bottom of the ocean and, off-screen, a baby's cry grows louder and louder. Showing Mina literally discarded and Haerim jettisoning her baby, the film establishes from the outset that not all is right with these two women.

In Managing the Monstrous Feminine, Jane Ussher examines how the reproductive female body is constructed as a site of danger, contamination, and monstrosity. ${ }^{12}$ If the Kristevan abject signifies "the body without boundaries," then the pregnant and post-natal body, with its protuberance and excretion (sweat, blood, excreta, afterbirth, breast milk), is the abject personified. And, according to Ussher, this abject body is deemed dangerous and monstrous because it "threatens the illusion of the contained, controlled, rational subject, and, as such, the stability and unity" of the social. Under this logic, then, Haerim and Mina are doubly abject, "mad" and "bad" women. Not only are they post-natal and pregnant, respectively, but they also undermine socially accepted ideas of motherhood as such: Haerim kills her own child (calling to mind Medea, the Ur-monstrous feminine) while Mina fails to responsibly take care of herself and, by extension, her child.

This cold monstrosity informs Haerim initially. Despite laboring in care work, she remains detached and unemotional: she never touches the old billionaire, works swiftly and without tenderness, and tells him, with

12 Jane M. Ussher, Managing the Monstrous Feminine: Regulating the Reproductive Body (London and New York: Routledge, 2006), 6. Ussher discusses various cultural, historical, religious, and scientific discourses that produce monstrosity in fecundity so as to control, manage, and regulate the female body. 
both scorn and envy, "I would die happily having lived like you for even a day." When the billionaire's son orders her to find Mina's next-of-kin, she complies in exchange for money - and goes so far as to force Mina's Alzheimer-ridden grandmother to sign the organ donation consent form. As her employer tells her, she "lacks even the semblance of cheap sympathy." Her living environment, a small one-room studio, looks unfeeling as well: white wallpaper, sparse furnishings, and bare windows make her home appear unlived and unlivable. Gaunt with hollow, sunken eyes, Haerim seems almost cadaverous and ghostly-barely alive. This is echoed in her employer's words that Haerim is "empty like her eyes"-and, in turn, "nothing" (amugŏttu anya). She appears a mere shell of lifenon-existent.

Sin Suwŏn was inspired by Norwegian painter Edvard Munch's $M a$ donna while writing the screenplay and made it the cover for her script. ${ }^{13}$ Without delving into Munch's life or oeuvre, it is worth noting that he was traumatized by the death of his mother when he was five years old, and his sense of abandonment is manifested in "the damaged and bruised maternal dyad ... the single maternal body with varied heads of the beatific virgin, seductive Madonna, self-abnegating martyr." ${ }^{14}$ His Madonna is one of these ambivalent and ambiguous images that show "a beautiful saintly Virgin and a seductress crowned by a red halo." Her closed eyes intimate orgasmic ecstasy, but her pulled-back arms suggest captivity and surrender; the smooth curves of her stomach offer serenity, but her twisted body indicates agony. When Haerim gives birth-eyelids fluttering, arms pulled aside, body contorted, alone in the reeds - the scene becomes a reproduction through performance of Munch's painting. She becomes

13 Kim Sujŏng, "Sŏ Yŏnghi egyesŏ mungk'ŭga poinda" (Seeing Munch’s Madonna in Sŏ Yŏnghi), Daum Film Magazine, July 3, 2015; Chang Byŏngho, "Sŭt'a intŏbu: Kim Yŏngmin” (Star Interview with Kim Yŏngmin”), Metro News, July 7, 2015.

14 Carol M. Ravenal, "Three Faces of Mother: Madonna, Martyr, Medusa in the Art of Edvard Munch," The Journal of Psychohistory 13, no. 4 (Spring 1986), 371-412. 
the haunting image of monstrous motherhood and of female selfsufficiency.

But what interests me beyond the Madonna/whore binary is the notion of spectrality in Munch's Madonna. While working on Madonna, Munch became fascinated by the camera and X-ray_ "spirit photograph" techniques for "captur[ing] ectoplasmic auras" and "confer[ring] spectrality" and the X-ray for making the invisible become visible. ${ }^{15}$ For this reason, the aural lines in his painting heighten a sense of eeriness and suggest the haunting presence of (an) absence. This ghostliness runs through Sin Suwŏn's Madonna as well, not merely for Haerim's ghostliness but because she is haunted by Mina. Having delivered the consent form to the son, Haerim bids Mina farewell. Captured from a low-angle so that she is looking down on Mina, Haerim says apathetically, "Be well in the afterlife." Just as Haerim turns to leave, however, she hears Mina's voice exclaim "wretched bitch" (pulssang'han nyŏn) — the very words that she had seen scrawled in Mina's squalid brothel room.

This scene marks a turning point for Haerim - and the film. She promptly returns to Mina and, for the first time, calls her by her name: "Mina-ssi!" At once startled and urged by her recognition of the subject within, that is, of Mina within the body to be killed, Haerim begins her quest to look for the latter. Looking has been productively examined by many feminist film scholars, such as Laura Mulvey and Mary Ann Doane, who problematize how the power of looking in narrative cinema belongs to man so that woman takes the position of the fetishized object of the male gaze. ${ }^{16}$ In Madonna, from this point on, Haerim becomes the holder of the gaze. Her position as looker is cemented when, in her birthing scene, she opens her eyes and stares at the camera. Haerim refuses the pas-

15 Sue Prideaux, "The Soul Laid Bare: Edvard Munch at Tate Modern," Tate Etc. 25 (2012), 31-37 (33-34, 36-37).

16 Laura Mulvey, "Visual Pleasure and Narrative Cinema," Screen 16, no.3 (October 1975); Mary Ann Doane, The Desire to Desire: The Woman's Film of the 1940s (Bloomington, IN: Indiana University Press, 1987). 
sive looked-at position of Munch's Madonna and, instead, wrests control of the camera's perspective and the film's narrative.

However, Haerim's looking is not at but for Mina. It is one that resists turning Mina into an object of viewing and, instead, insists on tracinghowever feeble the trace - and gathering. As Haerim tries to see-and imagines visions of-Mina, her actions illustrate what sociologist Avery Gordon, in Ghostly Matters, theorizes as "haunting." "17 For Gordon, to be haunted means to "confront the ghostly aspects of social life" and recognize how "that which appears to be not there is often a seething presence." 18 Defining "ghostliness" as the residue of an "unremembered past," she problematizes visibility as necessarily conditioned by power structures and calls for "putting life back in where only a bare trace was visible to those who bothered to look." ${ }^{19}$ To be haunted, then, is to trace the palimpsests of the past so as to revise what we see and know of the present. It is, as Haerim does, to rethink those who were subject to injustice and rendered $u n$-visible-like Mina. ${ }^{20}$

As an un-visible Mina is made visible, we see, alongside Haerim, a poor young girl who was always already labeled as an abject-Other as well as disposable. We see this in the way her naturally light hair causes her to be disciplined and ostracized at school, in the way her failed education causes her to resort to illicit means to support her grandmother, and in the way her fat unruly body causes her to be repeatedly harassed and exploited in the workplace. From middle school drop-out to call-operator to factory girl to prostitute, Mina's life is one of serial abuse that becomes

17 Avery F. Gordon, Ghostly Matters: Haunting and the Sociological Imagination (Minneapolis: University of Minnesota Press, 1997), 7.

18 Gordon, Ghostly Matters, 8

19 Gordon, Ghostly Matters, 22.

20 I distinguish "un-visible" from "invisible" based on Gordon's problematization of visibility as conditioned by power structures. "Un-visible" suggests a willful unwillingness on our part to see and recognize those like Mina who resideinsignificantly and precariously - in the margins of society. This un-visibility sediments over time so as to make one seem invisible. 
more and more punishing with time: she is beaten, harassed, molested, raped, nearly-killed - and, finally, discarded under a bridge and reduced to a mere organ. When her former schoolteacher remarks callously, "I forget that kids like her exist. They are just so insignificant and irrelevant," her words are a scathing reminder of how easy it is for people who fall wayside of social norms to descend into irrelevancy in our society.

Mina's irrelevancy is made clear with every accumulation of increasingly violent and sexual nickname: she is called "Brown Hair" (kalsaekmorri) and "Odd One" (óngttung'i) at school; "Madonna" at the insurance company; "Madam Udder" (chŏtsopuin) and "Porky Pussy" (samkyŏpsal poji) at the factory. The more "Mina" gets erased-and, consequently, fetishized into body-parts - the more she consumesgetting bigger and bigger until fully pregnant. But compensating for her erasure into non-existence with volume cannot save her from abjection, as both obesity and pregnancy suggest excess. ${ }^{21}$ Despite Mina's refrain-“I always do my best!"- - her best is never good enough: it is always too odd, too illicit, and too excessive. Beaten for day-dreaming, fired for following orders (both legal and illegal), and raped for reporting sexual harassment, Mina internalizes society's punishment of excess so that she instinctively blurts out in each of these instances: "I'm sorry! It's all $m y$ fault!"

Even a cursory viewer of Madonna can perceive its blatant critique of contemporary neoliberal society wherein capital reigns supreme and only the rich and productive are "worth" being kept alive. The billionaire's disease-ridden and deteriorating body needing Mina's young and healthy heart symbolizes this unforgiving and superficial economized society that is sustained through the exploitation of people like Mina as a cheap and reliable resource. Without mentioning neoliberalism per se, Sin Suwŏn has expressed contempt for such a society: "We seem to live in a society that keeps telling us, 'Do what you have to do. You're on your own.' We have no system but for one that slaves for the powerful $2 \%$."22 As politi-

21 Jane M. Ussher, Managing the Monstrous Feminine, 6.

22 Sin Suwŏn, Press Review for Madonna, June 11, 2015, CGV Wangsimri, Seoul, 
cal theorist Wendy Brown asserts, neoliberalism as a governing rationality always makes the individual responsible for itself through the semblance of "free" choice and, through its responsibilization, potentially dispensable. ${ }^{23}$ To thrive in such a society, then, is to be ruthless like the billionaire's son, immoral like the obsequious doctors at the VIP Ward, sexually manipulative and physically disciplined like the "full-time" female nurses and office workers; it is to not be like Mina or Haerim. ${ }^{24}$

In light of Madonna's tagline, "The choices we must live with," the film seems to narratively punish both Haerim and Mina for their poor "choices." Thus, when Haerim tries to save Mina's baby, it seems she does so to correct her earlier decision to drown her own child. Upon closer viewing, however, it is possible to read her action as one driven not by individual choice or maternal remorse but by ethical responsibility. For the more Haerim traces Mina's life, the more clearly Mina appears to Haerim: from a specter to a voice to a visitation. This final moment of encounter occurs when Haerim lies down on Mina's empty bed (after she has been taken to the operating room for the organ harvest). As if merging with Mina's ghost in this process, Mina materializes in front of Haerim. The two are framed so that they are represented equally, and the blue hospital bed, like the water flowing from Mina to Haerim in the opening title sequence, acts as a bridge between the two women and erases the boundaries of self and other.

Korea.

23 Wendy Brown, "Sacrificial Citizenship: Neoliberalism, Human Capital, and Austerity Politics," Constellations 23, no. 1 (March 2016), 3-14; Undoing the Demos: Neoliberalism's Stealth Revolution (New York: Zone Books, 2015), 30-34.

24 While men most often wield power and violence (all bosses, doctors, and perpetrators are male), Madonna does not sanctify women. Some of the meanest and basest deeds are enacted on women by women, such as Mina's brothel madam. Even the seemingly "good" ones, such as Mina's only friend at the insurance company, are not exempt from replicating the same violence as the men, such as demeaning and objectifying an attractive female colleague by calling her "jjalch ' $i$," a portmanteau for short (jjalbün) skirts (ch'ima). 
Here, Haerim confesses that she killed her baby to save herself and questions why Mina did not abort hers: "This baby has no worth (kach'i). It wasn't borne of love." Mina calmly replies that the baby-despite borne of rape - depends on her, and that is love enough. Mina then wipes Haerim's tears, brushes her hair, and leaves. Enraptured by this encounter, Haerim rushes to the billionaire and tells him with sincerity that two lives are about to be sacrificed for him. Clasping his hand in hers, as if in prayer, she takes his single blink as permission and pulls the plugs. Hearing the news of his death, the doctors decide to save Mina's baby. As Mina dies while giving birth, the film offers another water sequence: Mina, dressed in a translucent white gown, plunges into the water, rescues a smiling cherubic baby from Haerim's suitcase, and resurfaces. If she had been "Madonna," the big-breasted prostitute, she is now Madonna, the virgin(al) "guardian of children." 25

What are we to make of this sequence? Why does Mina save Haerim's baby just as Haerim saves Mina's? Does this recuperate the two women as life-affirming mothers? Does Madonna, with its abundance of water imagery, reproduce the mother's womb as a metaphor for mercy, forgiveness, and redemption? Are the two women, initially inscribed as utterly abject and monstrous, sanctified and purified by maternal suffering - and, thereby, re-contained by an oppressive socio-cultural order ${ }^{26}$ Does Madonna submit to notions of "the beneficent Madonna, the ideal-

25 Simone de Beauvoir, The Second Sex, trans. and ed. H. M. Parshley (New York, Knopf, 1953), 80-81. De Beauvoir defines the Virgin Mary, "the Lady with healing hands," "guardian of children," "wellspring of life, "as the feminine ideal within Western patriarchy.

26 Barbara Creed cites Kristeva to argue that religion and art function to purify the abject by redrawing boundaries and excluding all that threaten the stability of the symbolic order. Kristeva also scrutinizes the Virgin Mary's historical role as cultural construct and maternal "ideal." Barbara Creed, "Kristeva, Femininity, Abjection," The Horror Reader, ed. Ken Gelder (New York: Routledge, 2000), 64-70; Julia Kristeva, "Stabat Mater," The Kristeva Reader, trans. and ed. Toril Moi (New York: Columbia University Press, 1986), 160-185. 
ized female beauty, the 'eternal feminine,' who driv[es] all notions of monstrosity aside" ${ }^{27}$ And, as such, is motherhood, indeed, the highest womanhood? Is saving Mina's baby representative of a reality that values fetal citizenship - as the survival of the future - above all others? While all of these interpretations are certainly possible, it is noteworthy that both Haerim and Mina are, in the end, not mothers.

Haerim and Mina do not save each other's babies as mothers; rather, they save each other as women. This explains why after all the trouble Haerim undergoes to save Mina's baby, she does not stay behind to mother her, but, in fact, leaves her. Haerim, who killed her baby so that she could live, does not harbor any newfound fantasy of motherhood simply for having saved Mina's baby. Hence, she is never seen with the baby upon its birth and only enters the baby's life-through a mailed letter narrated in voiceover - to belatedly name her "Mina." And her choice of "Mina" seems to avail another chance at life to Mina more so than to the baby. In this sense, the trope of motherhood is exactly that - a trope. It serves to evoke a common sensibility only to have Haerim, resolute in her denial of motherhood, shatter it. Haerim challenges the myth of motherhood and maternal love as uniform or totalizing and remains unsympathetic from start to finish.

That we are not given a backstory to Haerim is also significant. We are never privy to how she became pregnant or why she chose to kill her baby after carrying it to full-term. In this lack of knowledge, Madonna seems to say that it is enough that she did so. For the absence of any support, whether personal (baby's father or family) or social (clinics or welfare systems), is testament enough to the sheer difficulty of being a poor and unskilled single-mother in contemporary Korea. Haerim's decision to kill her child for whatever reason also sheds light on certain moral transgressions that are enacted and overlooked in the name of motherhood in Korean society. One need only consider phrases like ómmaŭi ch'ima param (swish of mom's skirt) and the neologism toejiŏmma (pig mom) to recog-

27 Jane M. Ussher, Managing the Monstrous Feminine, 2. 
nize how mothering in Korea is often accompanied by an excessive ownership of one's children. ${ }^{28}$ Seen in this light, Madonna does not reinforce a limited ideal of motherhood as sacrificial and life-saving but, rather, reveals it as isolating, restrictive, selfish, and detrimental.

Perhaps, then, another reading of Madonna is possible. If Haerim's will to remember re-collects and re-members Mina, that is, "put[s] life back" into Mina by "bother[ing] to look," Mina also teaches Haerim that life is one of interdependence - not one measured by "worth" or ownership. For Mina, her baby is "love" and gives her the will to live because it necessitates the recognition of vulnerability and interdependency. In this sense, what Haerim and Mina do for each other can be seen as a Levinasian encounter of the Other's suffering and pain. For Levinas, individuality or subjectivity is always "intersubjective." In the words of Levinas, "I am defined as a subjectivity, as an 'I,' precisely because I am exposed to the other. It is my inescapable and incontrovertible answerability to the other that makes me an individual 'I.",29 If the abject is the loss of the distinction between subject and object, between self and other, their encounter can be seen as a recovery of this distinction.

Indulging this thought a little further, Madonna questions what it means to be (and live as) human — and the kind of change that this ethical

28 The "pig mom" is the quintessential neoliberal mother who researches, organizes, and strategizes (at times illegally) access to the best academic network, including the best hagwŏns (private after-school institutions) and private teachers, with the ultimate goal of admission into one of the three most prestigious universities in Korea: Seoul National, Yonsei, and Korea Universities. A "pig mom" leads a select group of mothers who are equally wealthy and invested in their children's education and future. Such "pig moms" not only make and break hagwŏns but also impact the real estate market in Seoul. The word toeji, meaning "pig," is meant to suggest wealth and coddling and plays on Taech'i-dong, the affluent education "mecca" in the Kangnam district of Seoul.

29 Emmanuel Levinas and Richard Kearney, "Dialogue with Emmanuel Levinas," Face to Face with Levinas, ed. Richard A. Cohen (Albany: SUNY Press, 1986), 26-27. 
and empathetic questioning can bring forth. Madonna closes with Haerim's voiceover - a letter to Mina's baby (now sleeping peacefully in a bright sunlit nursery). Haerim tells the baby: "I don't know who your mother was. Nothing's certain about how your mother lived her life. But there's one thing I must tell you. Two lives were sacrificed for you. So I hope you live a happy and valued (kapjin) life." The ending is at once ambiguous and ambivalent. It is unclear whose lives Haerim refers to in "two lives": Mina and the billionaire or Mina and Haerim's baby. And, in naming the baby "Mina," there is a sense that this baby may either follow her mother into precarity or give Mina a second chance at a "happy and valued life" - not an "insignificant and irrelevant" one.

Moreover, as Haerim emphasizes, "nothing is certain" about Mina's life. What little we see and know of Mina are mere fragments of memories that are painfully collected and (re)imagined by Haerim. This is testament to how such a bare life like Mina's needs a dogged listener, interlocutor, storyteller to piece together such a life — and attest to a self. Yet, doing so is what allows Haerim to recover her sense of self so that the last image of Haerim is of her moving forward in a packed bus - mustering a small smile. Haerim shows that once we see what we did not see before and know in a way that we did not know before, we can no longer un-see or un-know. This is a call not only for empathetic understanding but also for intervention. It is to participate in the ethical act of bearing responsibility toward an other and to create transformative knowledge so that we can work towards recuperating life - not as bare and disposable but as undiminished and worthwhile.

As Judith Butler states in Precarious Life, the question of the humanwho counts as human and whose life counts as a life that matters-is crucial to imagining a political community. She asserts that "the ties we have to others ... constitute what we are ... the attachment to 'you' is part of what composes who "I" am." ${ }^{, 30}$ Since we all "live with a vulnerability to

30 Judith Butler, Precarious Life: The Powers of Mourning and Violence (London and New York: Verso, 2004), 22. 
the other," we need to recognize that "vulnerability becomes highly exacerbated under particular conditions," and, thus, "attend to," "critically evaluate," and "oppose the conditions under which certain human lives are made more vulnerable than others." ${ }^{31}$ For Butler, we are always already involved in a reciprocal exchange, and a political community requires this recognition: "I cannot think the question of responsibility alone; if I do, I have taken myself out of the relational bind that frames the problem of responsibility. I cannot muster the 'we' except by finding the way in which 'I' am tied to 'you.",32

Haerim's and Mina's powerless encounter produces a potency to vivify a horizontal community — one that can (hopefully) interrupt the verticality of neoliberal society. In watching the film, we follow Haerim trace fragments and incongruities left behind by Mina, and we begin to make contact with what is painful, difficult, and unsettling. By reflecting back on a world that makes us "bother to look" so as to see that our lives are valued more (or less) than others, Madonna challenges us to be surprised, imaginative, and critical - to realize ethical responsibility as a demanding endeavor. If, following Butler, we can only affirm our own lives by critically evaluating those structures that differentially value life, Madonna draws us affectively into this process of affirmative encounter. Our response to the film's question, "Does anyone know this girl?" is that, when we become critical of those categories and structures that produce such effacement and inequality, we all do.

31 Judith Butler, Precarious Life, 29-30.

32 Judith Butler, Precarious Life, 43-46. 
